American Journal of Applied Sciences 6 (10): 1820-1825, 2009

ISSN 1546-9239

(C) 2009 Science Publications

\title{
Competition Effects of Date of Sowing and Nutsedge Removal Time on Yield and Yield Contributing Characters of Tef [Eragrostis tef (Zucc.) Trotter]
}

\author{
${ }^{1}$ Abdul Shukor Juraimi, ${ }^{2}$ Mahfuza Begum, \\ ${ }^{1,3}$ Ahmed Mohammed Sherif and ${ }^{1}$ Anuar Abdul Rahim \\ ${ }^{1}$ Faculty of Agriculture, University Putra Malaysia, Malaysia \\ ${ }^{2}$ Institute of Tropical Agriculture, University Putra Malaysia, 43400 Serdang, Selangor, Malaysia \\ ${ }^{3}$ Ethiopian Agricultural Research Organization, Debre Zeit, Ethiopia
}

\begin{abstract}
Problem statement: Tef [Eragrostis tef (Zucc.) Trotter] is a $\mathrm{C}_{4}$ grass, most important indigenous cereal crop in Ethiopia. The average grain yield of this crop is low; averaging $<0.8 \mathrm{Mg} \mathrm{ha}^{-1}$. Under appropriate cultural practices such as the right sowing date, sowing rate, weeding time and fertilizer application, tef could produce grain yields of $2200-4599 \mathrm{~kg} \mathrm{ha}^{-1}$. A delay in planting beyond recommended date a substantial yield reduction might be occurred. On the other hand, surveys showed that purple nutsedge (Cyperus rotundus $\mathrm{L}$.) is a noxious weed present in varying abundance in tef. Yield loss due to nutsedge alone could be as high as $42 \%$ in agronomic crops. In addition, tef as well as purple nutsedge possesses the highly efficient $\mathrm{C}_{4}$ dicarboxylic acid photosynthetic pathway, which enhances their potential as high yielding crops or serious weeds. Studies on competitive ability of tef with improved cultural practices would provide more effective weed suppression and economic benefits to famers in Ethiopia, where chemical control is economically not feasible. The competitive effect between tef and purple nutsedge, both $\mathrm{C}_{4}$ species, has not been studied yet. Hence, this paper deals with the effects of delay in tef sowing date and nutsedge removal time on growth and yield of tef. Approach: Tef was planted at three sowing dates, recommended sowing date, 7 and 15 days delay after the recommended date. The five weed removal time were included as weedy check (W1), weeded 2 weeks (W2), 4 weeks (W3), 6 weeks (W4) after crop emergence and weed-free check (W5). All data were subjected to analysis by SAS, correlation/regression analysis and treatment means were compared using Tukeys Test. Results: Weed removal time played a minor role compared to sowing time. Irrespective of weeding dates, delayed tef sowing was very critical. When sowing was delayed for 7 and 15 days, reduction of plant height by 6.97 and $11.53 \%$, panicle length by 8.21 and $12.32 \%$ and grain yield by 15 and $16 \%$, respectively There was relationship among plant height, biomass and grain yield, where by grain yield responds positively to taller plants and higher biomass when the crop is sown early in the season. Hence, tef was more competitive than nutsedge. Early sowing of tef is essential to increase crop growth and yield. Conclusion/Recommendations: Increase in plant height, panicle length and a corresponding increase in tef grain yields, provided that there was no delay in sowing of tef at all.
\end{abstract}

Key words: Cyperus rotundus, debre zeit, sowing time, tef [Eragrostis tef (Zucc.) trotter], weeding regime

\section{INTRODUCTION}

Tef, [Eragrostis tef (Zucc.) Trotter] is the only cultivated cereal in the genus Eragrostis under the family Poaceae. Ethiopia is the center of origin of tef ${ }^{9 \text {, }}$ ${ }^{18]}$ and is the only country in the world that uses tef as a cereal crop ${ }^{[6]}$. Ethiopian farmers prefer tef, because the grain and straw bring good prices. Tef is also culturally deep entrenched in the food-habit of the Ethiopian population. Tef occupies $31 \%$ of the total farmland area of that country ${ }^{[14]}$. Its production area is increasing at unprecedented scale due to increased market-demand both local and foreign. One of the most important characteristics that make tef an efficient crop in arid and semi arid areas is its $\mathrm{CO}_{2}$ assimilation efficiency as a $\mathrm{C}_{4}$ species $^{[10]}$. Physiological advantages of $\mathrm{C}_{4}$ photosynthesis include higher rates of $\mathrm{CO}_{2}$ fixation, reduced photorespiration and decreased transpiration.

Corresponding Author: Mahfuza Begum, Institute of Tropical Agriculture, University Putra Malaysia, 43400, Serdang, Selangor, Malaysia Tel: 0169763538 
Therefore, $\mathrm{C}_{4}$ plants grow faster, become larger and are more competitive than $\mathrm{C}_{3}$ plants ${ }^{[12]}$.

Adaptation of diverse biotic and abiotic stresses has made tef a low risk crop for cultivation ${ }^{[14]}$. Tef performs well above any other crops under unfavorable circumstances such as drought and water logging ${ }^{[1,11]}$. In addition, adaptation of tef to different climatic and soil conditions has exposed it to grow in association with a diverse weed flora. Most surveys indicate that weed control in tef remains to be one of the most expensive, as well as time and energy consuming operation with little success in increasing tef productivity. As regards yield losses in tef, Fissehaie and Tadele ${ }^{[5]}$ have reported that countrywide yield losses due to weeds varied from 23-65\%. Ketema, $1997^{[11]}$ reported that a yield loss of tef due to weeds in Ethiopia was $17.8 \%$. It is believed that delay in removing weeds beyond 2-4 weeks after sowing may result in crop losses exceeding $10 \%$ and the majority of the highland crops yield 5 or $10 \%$ below than attainable yields. Weed counts at 4 weeks after planting showed significantly higher weed densities in the zero tillage compared to minimum, conventional and broad bed furrows tillage treatments ${ }^{[17]}$. Under conditions where weeding is less and perennial weeds are a problem, crop losses due to weeds range from $10-50 \%$, with a conservative estimate of $20 \%$. Analysis of all surveys and investigations indicate, an over all realistic estimate of $25 \%$ yield loss due to weeds, which should be regarded as a serious loss to the farmer as well as the country as a whole ${ }^{[12]}$. Being a cash crop, the little tef yield increment contributes a significant role in the striving of food deficit towards food security ${ }^{[15]}$.

Under appropriate cultural practices, it is possible for farmers to produce up to $2200-4599 \mathrm{~kg} \mathrm{ha}^{-1}$ tef grain yield ${ }^{[16]}$. However, under ideal research conditions, Asefa et al. ${ }^{[2]}$ and Habtegebrial and Singh ${ }^{[7]}$ have found that tef could produced grain yield $32-61 \%$ higher than the farmers yield. Therefore, the study of the competitive effect of purple nutsedge on different yield components and yield of tef was necessary in order to determine feasible cultural control measures. Hence, this paper deals with the relationship between yield and yield contributing characters of tef with respect to time of sowing date and nutsedge removal time.

\section{MATERIALS AND METHODS}

The experiment was conducted at Debre Zeit Agricultural Research Center during the period July to December 2004. It is situated at an altitude of 1960 meters above sea level. It is one of the major tef growing areas in the country. It has a warm climate with temperatures ranging from $7^{\circ} \mathrm{C}$ to a maximum of $30^{\circ} \mathrm{C}$. The rainfall is more-or-less stable ranging from no-rain around November to as high as $750 \mathrm{~mm} \mathrm{month}^{-1}$ during the rainy season from June to October. It has black-clay soil (sand 10, silt 16 and clay 74), with high water holding capacity.

The plot size was $3 \times 3 \mathrm{~m}$ with harvestable area of $2.5 \times 2.5 \mathrm{~m}$ and footpaths of $1 \mathrm{~m}$ between plots and $2 \mathrm{~m}$ between replications. The experiment was laid down in a $3 \times 5$ factorial in randomized complete block design with four replications. Three dates of sowing and five dates of weeding were used as treatments. The three dates of sowing were: recommended date of planting tef (first sowing date S1, second week of July), sowing delayed by seven days after the first sowing date (S2) and sowing delayed by 15 days after the first sowing date (S3). The five weeding treatments were: Weedy check (W1); weeded two weeks after crop emergence (W2); weeded 4 weeks after crop emergence (W3); weeded 6 weeks after crop emergence (W4); and weedfree check (W5). The weedy-check was left weedy with purple nutsedge (i.e., all other weeds were uprooted and only nutsedge remained) for the whole season. The naturally occurring high infestations of purple nutsedge were considered for competition. In contrast, the weed-free-check was clean of all weeds, including purple nutsedge. Hence, weeding in this experiment means weeding the nutsedge; weeds other than nutsedge were regularly rouged out to make the competition only between tef crop and purple nutsedge.

The tef variety used was DZ-1-354 at $30 \mathrm{~kg} \mathrm{ha}^{-1}$. Sowing of tef was carried out manually by broadcasting because tef is not yet a mechanized crop. DAP and urea fertilizers at the rate of $100 \mathrm{~kg} \mathrm{ha}^{-1}$ of each were applied at sowing and during mid-season of the crop on all plots, respectively. All data were subjected to ANOVA, Principal Component Analysis (PCA) and correlation/regression analysis. PCA can be used to reduce a large amount of data into a manageable size. Among the parameters taken, those that contributed more, based on Principal Component Analysis, were considered here. The number of parameters was reduced from 12-4 and together with yield data. Tukey's studentised range test (Tukey Grouping) was used for means comparison to compare treatment means.

\section{RESULTS}

Principal component analysis carried out on yield and yield contributing parameters of tef showed that plant height, panicle length, spikelet number and biomass had contributed 30, 27, 13 and 9\%, respectively to grain yield of tef. 
Am. J. Applied Sci., 6 (10): 1820-1825, 2009

Table 1: Effect of delayed sowing and weed removal time on tef height

\begin{tabular}{lllll}
\hline & \multicolumn{2}{l}{ Delayed sowing* } & & \\
Weed removal & -0 day (S1) & 7 days (S2) & 15 days (S3) & Weed removal mean** \\
\hline Weedy check (W1) & $(1) 89 \mathrm{abc}$ & $(6) 84 \mathrm{abc}$ & $(11) 78 \mathrm{c}$ & $83.41 \mathrm{~d}$ \\
Weeded 2wae* (W2) & $(2) 89 \mathrm{abc}$ & $(7) 89 \mathrm{abc}$ & $(12) 77 \mathrm{c}$ & $85.00 \mathrm{~d}$ \\
Weeded 4wae (W3) & $(3) 91 \mathrm{ab}$ & $(8) 89 \mathrm{abc}$ & $(13) 84 \mathrm{abc}$ & $87.83 \mathrm{~d}$ \\
Weeded 6wae (W4) & $(4) 93 \mathrm{ab}$ & $(9) 86 \mathrm{abc}$ & $(14) 79 \mathrm{bc}$ & $85.67 \mathrm{~d}$ \\
Weed-free check (W5) & $(5) 93 \mathrm{ab}$ & $(10) 77 \mathrm{c}$ & $(15) 86 \mathrm{abc}$ & $80.25 \mathrm{~d}$ \\
Delayed sowing mean*** & $91.05 \mathrm{e}$ & $84.70 \mathrm{f}$ & & \\
CV $(\%)$ & & 8.99 & & \\
\hline
\end{tabular}

*: Means of treatment combinations followed by the same letter are not significantly different (HSD, $\mathrm{p}<0.05)$; **: Means of weed removal treatments followed by the same letter in a column are not significantly different (HSD, p $<0.05)$; ***: Means of delayed sowing followed by the same letters in rows are not significantly different (HSD, $\mathrm{p}<0.05)$; Figures in parentheses (1-15) are treatment numbers. Wae: Weeks after crop emergence

Table 2: Effect of delayed sowing and weed removal time on tef panicle length

\begin{tabular}{lllll}
\hline & Delayed sowing* & & \\
Weed removal & 0 day (S1) & 7 days (S2) & 15 days (S3) & Weed removal mean** \\
\hline Weedy check (W1) & $(1) 34.25 \mathrm{a}$ & $(6) 30.25 \mathrm{abc}$ & (11) 30.00abc & $31.50 \mathrm{~d}$ \\
Weeded 2wae* (W2) & $(2) 31.25 \mathrm{ab}$ & $(7) 26.00 \mathrm{bc}$ & (12) 29.25abc & $29.08 \mathrm{dc}$ \\
Weeded 4wae (W3) & $(3) 30.50 \mathrm{ab}$ & $(8) 28.50 \mathrm{ab}$ & $(13) 30.000 \mathrm{abc}$ & $29.66 \mathrm{dc}$ \\
Weeded 6wae (W4) & $(4) 31.25 \mathrm{ab}$ & $(9) 30.75 \mathrm{ab}$ & $(14) 25.25 \mathrm{bc}$ & $29.08 \mathrm{~d}$ \\
Weed-free check (W5) & $(5) 3100 \mathrm{ab}$ & $(10) 29.75 \mathrm{abc}$ & $(15) 23.75 \mathrm{c}$ & $28.16 \mathrm{~d}$ \\
Delayed sowing mean*** & $31.65 \mathrm{e}$ & $29.05 \mathrm{ef}$ & & $27.75 \mathrm{f}$ \\
$\mathrm{CV}(\%)$ & 13.60 & & \\
*: Means of treatment combinations followed by the same letter are not significantly different (HSD, p<0.05); **: Means of weed removal \\
treatments followed by the same letter in a column are not significantly different (HSD, p<0.05); ***: Means of delayed sowing followed by the \\
same letters in rows are not significantly different (HSD, p<0.05); Figures in parentheses (1-15) are treatment numbers. Wae: Weeks after crop \\
emergence
\end{tabular}

Table 3: Effect of delayed sowing and weed removal time on grain yield

\begin{tabular}{|c|c|c|c|c|}
\hline \multirow[b]{2}{*}{ Weed removal } & \multicolumn{3}{|c|}{ Delayed sowing* } & \multirow[b]{2}{*}{ Weed removal mean** } \\
\hline & 0 day (S1) & 7 days (S2) & 15 days $(\mathrm{S} 3)$ & \\
\hline Weedy check (W1) & (1) $1600 \mathrm{abc}$ & (6) $1320 \mathrm{bc}$ & (11) $1280 \mathrm{c}$ & $1400 \mathrm{~d}$ \\
\hline Weeded 2wae* (W2) & (2) $1580 \mathrm{abc}$ & (7) $1375 \mathrm{abc}$ & (12) $1440 a b c$ & $1465 \mathrm{~d}$ \\
\hline Weeded 4wae (W3) & (3) $1800 \mathrm{a}$ & (8) $1250 \mathrm{c}$ & (13) $1220 \mathrm{cabc}$ & $1423 d$ \\
\hline Weeded 6wae (W4) & (4) $1740 \mathrm{ab}$ & (9) $1520 \mathrm{abc}$ & (14) $1600 \mathrm{abc}$ & $1620 \mathrm{~d}$ \\
\hline Weed-free check (W5) & (5) $1760 \mathrm{abc}$ & (10) $1480 \mathrm{abc}$ & (15) $1320 \mathrm{bc}$ & $1420 \mathrm{~d}$ \\
\hline Delayed sowing mean*** & $1636 \mathrm{e}$ & $1389 \mathrm{f}$ & $1372 \mathrm{f}$ & \\
\hline $\mathrm{CV}(\%)$ & 17.47 & & & \\
\hline
\end{tabular}

Weed removal time had no significant influence on above mentioned yield and yield contributing characters of tef. Sowing dates also had no significant difference on spikelet numbers and tef biomass (data not shown). However, in plant height, timely sown tef (S1) was more competitive against nutsedge than tef sown at second (S2) and third (S3) sowing dates, since plant height in timely sown tef was significantly higher than the delayed sown tef at second (S2) and third (S3) sowing dates. Plant height reduction was 6.97 and $11.53 \%$ due to delayed sowing for 7 and 15 days, respectively irrespective of weeding dates (Table 1). The average panicle length in early sowing date (S1) was significantly different and longer from third sowing date (S3), but there was no significant difference between the first and second sowing dates as well as between the second and third sowing dates (Table 2). The reduction in panicle length due to delay in sowing for 15 days was $12.32 \%$. In case of grain yield the plants produced significantly higher grain yield in the first sowing date compared to the second and third sowing dates (Table 3). Hence, there were yield reductions of 15 and $16 \%$ due to sowing delay of 7 and 15 days, respectively.

Regarding the relationship between crop biomass and plant height, there was slightly positive relationship 
Am. J. Applied Sci., 6 (10): 1820-1825, 2009

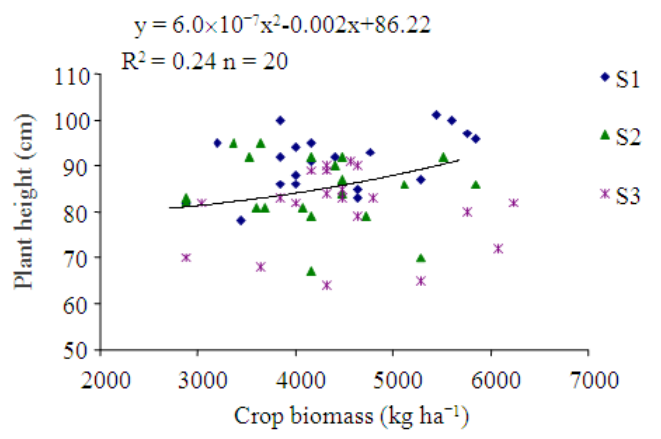

Fig. 1: Relationship between crop biomass and plant height with respect to sowing date of tef

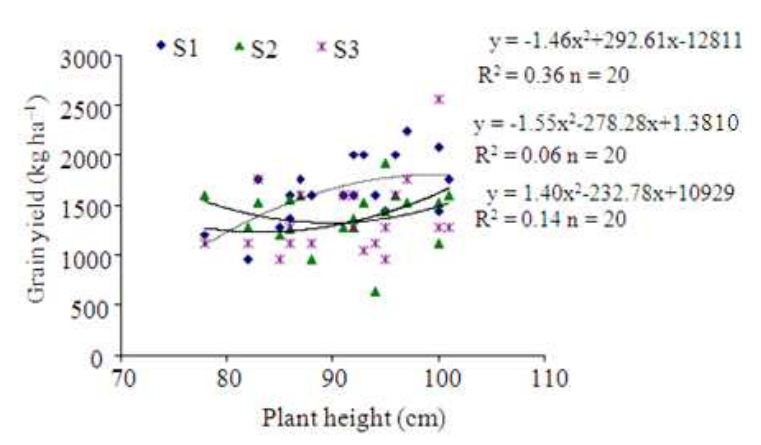

Fig. 2: Relationship between plant height and grain yield with respect to sowing date of tef

between crop biomass and plant height with respect to early sowing. As the biomass increased the height also increased ( $\mathrm{S} 1 \mathrm{y}=6.0 \times 10^{-7} \mathrm{x}^{2}-0.001 \mathrm{x}+86.22, \mathrm{R}^{2}=0.24$, Fig. 1). The relationship between panicle length and grain yield in the early sowing date (S1) showed as panicle length increased grain yield was also increased at first and then decreased and quadratics relationship was weak $\left(R^{2}=0.16\right)$. At that sowing date relationship between spikelets number and grain yield of tef was positive ( $\mathrm{S} 1, \mathrm{y}=4.52 \mathrm{x}^{2}-96.50 \mathrm{x}+1688.4, \mathrm{R}^{2}=0.39$, data not shown). However, the relationship between plant height and grain yield was stronger with respect to first sowing date compared to late sowing $\left(\mathrm{S} 1 \mathrm{y}=-1.46 \mathrm{x}^{2}+292.61 \mathrm{x}-12811, \mathrm{R}^{2}=0.34\right.$, Fig. 2$)$. The response of grain yield to crop biomass in general was quadratic and positive but the attribute was not high $\left(y=-6.0 \times 10^{-5} x^{2}+0.73 x-521.04, R^{2}=0.22\right.$, Fig. 3). The predicted biomass for a maximum grain yield of 1700 $\mathrm{kg} \mathrm{ha}^{-1}$ was $6000 \mathrm{~kg} \mathrm{ha}^{-1}$. Partitioning the data for sowing dates showed a positive linear relationship between crop biomass and grain yield for early sowing $\left(\mathrm{S} 1, \mathrm{y}=0.31 \mathrm{x}+281.16, \mathrm{R}^{2}=0.66\right.$, Fig. 4). Early sowing resulted in higher grain yields largely due to reduced weed competition.

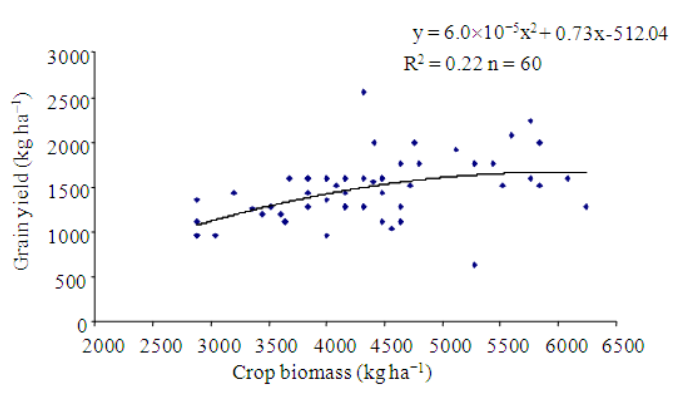

Fig. 3: Relationship between crop biomass and tef grain yield

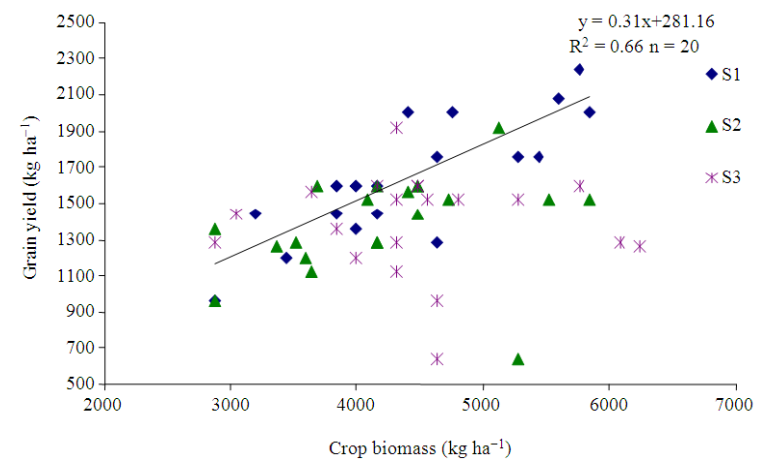

Fig. 4: Relationship between crop biomass and tef grain yield with respect to tef sowing date

\section{DISCUSSION}

An increase in panicle length was associated with increase in spikelets number and a corresponding increase in grain yields of tef, provided sowing is carried out without delay. In this experiment longer the delay in sowing the shorter the panicle length. This implies that leaving weeds to grow before crop sowing, will have effect on different parts of the plants and subsequently negatively affects the grain yield of tef. Firbank and Watkinsson ${ }^{[4]}$ mentioned that even the slightest variation in emergence time could affect grain yield, either by altering the time available for growth or by giving earlier emerging plants a competitive advantage. Hundera et $a l^{[8]}$ reported that a delay in tef sowing date beyond the recommended time would reduce yield by $30 \%$.

In this study, among the four characteristics plant height and panicle length contributed 57\% to grain yield, whereas spikelet number and tef biomass together contributed $22 \%$ to grain yield. According to Tefera et $a l .{ }^{[13]}$ these above mentioned traits exhibited high and positive direct effects on grain yield. While Teklu and tefera ${ }^{[16]}$ observed that improved plant 
height, panicle length and kernels per panicle were a feature of most modern acceptable genotypes. They found that stepwise regression analysis of grain yield on selected yield components revealed that number of spikelets and biomass yield were the most important attributes, which accounted for $56.7 \%$ of the variation in grain yield. According to the literature, higher photosynthetic rate of $\mathrm{C}_{4}$ species also results in more dry matter production per unit of input utilization. Ketema $^{[11]}$ had reported that tef plants produced more than $5,000 \mathrm{~kg} \mathrm{ha}^{-1}$ of green material within a period of three months. In favorable environmental conditions and ample inputs, tef could produce $6,355-19,630 \mathrm{~kg} \mathrm{ha}^{-1}$ of total biomass ${ }^{[2]}$. In line with these findings, in the present experiment, the predicted biomass for a maximum grain yield of 1700 was $6000 \mathrm{~kg} \mathrm{ha}^{-1}$ tef biomass.

In this study, timely sown tef produced 17.78 and $19.24 \%$ higher yield compared to sowing in delay at 7 and 15 days respectively. Belay et al. ${ }^{[3]}$ opined that by any standards, a $13.5 \%$ yield advantage is quite high. Adnew et al. ${ }^{[1]}$ observed that diversity within the regions was found to be significant and, hence an opportunity for exploitation of tef improvement by proper management.

\section{CONCLUSION}

Delayed sowing of tef by 7 and 15 days had resulted in reduction of plant height by 6.97 and $11.53 \%$, panicle length by 8.21 and $12.32 \%$ and grain yield by 15 and $16 \%$, respectively. The relationship between plant height and grain yield and crop biomass and grain yield of tef was positive, whereby, as the plant height as well as crop biomass increased, the yield also increased. All these relationships clearly indicate the high competitive ability of tef against nutsedge.

\section{ACKNOWLEDGEMENT}

We would like to thank the Agricultural Research and Training Program (ARTP) and Ethiopian Agricultural Research Organization (EARO) for financial support and facilitating this study in Malaysia and Tef Research Program of Debre zeit agricultural research center as well as the management of Debre zeit Agricultural Research Center for providing research facilities for fieldwork, workers and transport.

\section{RFERENCES}

1. Adnew, T., S. Ketema, H. Tefera and H. Sridhara, 2005. Genetic diversity in tef [Eragrostis tef (Zucc.) Trotter] germplasm. Genet. Resour. Crop Evolut., 52: 891-902. DOI: 10.1007/s10722-0036099-0
2. Asefa, K., S. Ketema, H. Tefera, F Hundera and T. Kefyalew, 2001. Genetic diversity for agronomic traits in tef. Narrowing the Rift: Tef research and development. Proceedings of the International Workshop on Tef Genetics and Improvement, Oct. 16-19, Ethiopian Agricultural Research Organization, Debre Zeit, Ethiopia, pp: 33-48.

3. Belay, G., H. Tefera, A. Getachew, K. Assefa and G. Metaferia, 2008. Highly client-oriented breeding with farmer participation in the Ethiopian cereal tef [Eragrostis tef (Zucc.) Trotter]. Afr. J. Agric. $\quad$ Res., $\quad 3$ 22-28. http://www.academicjournals.org/ajar/PDF/pdf\%2 02008/Jan/Belay\%20et\%20al.pdf

4. Firbank L.G. and A.R. Watkinsson, 1990. On the Effect of Competition: From Monoculture to Mixture. In: Perspective on Plant Competition, Grace, J.B. and D. Tilman, (Eds.). Academic Press Inc., San Diego, ISBN: 9781930665859, pp: 484.

5. Fissehaie, R. and Z. Tadele, 2001. Weed research in Tef. Narrowing the Rift: Tef research and development. Proceedings of the International Workshop on Tef Genetics and Improvement, Ethiopian Agricultural Research Organization, Oct. 16-19, Debre Zeit, Ethiopia, pp: 1-361.

6. Gugsa, L., G. Belay and S. Ketema, 2001. The cytogenetics of tef. Narrowing the Rift: Tef research and development. Proceedings of the International Workshop on Tef Genetics and Improvement, Oct. 16-19, Ethiopian Agricultural Research Organization, Debre Zeit, Ethiopia, pp: 49-57.

7. Habtegebrial, K. and B.R. Singh, 2006. Effects of timing of nitrogen and sulphur fertilizers on yield, nitrogen and sulphur contents of Tef (Eragrostis tef (Zucc.) Trotter). Nutr. Cycl. Agroecosyst., 75: 213-222. DOI: 10.1007/s10705-006-9028-8

8. Hundera, F., T. Bogale, H. Tefera, K. Asefa, T. Kefyalew, A. Debelo and S. Ketema, 2001. Agronomy research in tef. Proceedings of the International Workshop on Tef Genetics and Improvement, Oct. 16-19, Debre Zeit, Ethiopia, pp: 167-174.

http://www.fao.org/agris/search/display.do?f=./200 3/v2908/ET2003000046.xml;ET2003000046

9. Jones, B.M., G.J. Ponti, A. Tavassoli and P.A. Dixon, 1978. Relationships of the Ethiopian cereal tef (Eragrostis tef (Zucc.) Trotter): evidence from morphology and chromosome number. Ann. Bot., 42: 1369-1373. 
10. Kebede, H., R.C. Johnson and D.M. Ferris, 1989. Photosynthetic response of Eragrostis tef to temperature. Physiol. Plant, 77: 262-266. DOI: 10.1111/j.1399-3054.1989.tb04979.x

11. Ketema, S., 1997. Tef [Eragrostis tef Zucc. Trotter]. Promoting the conservation and use of under-utilized and neglected crops. International Plant Genetic Resource Institute, Rome, Italy. http://www.bioversityinternational.org/Publications /Pdf/279.pdf

12. Raghavendra, A.S. and V.S. Rama Das, 1993. $C_{4}$ Photosynthesis and $\mathrm{C}_{3}-\mathrm{C}_{4}$ Intermediacy: Adaptive Strategies for Semiarid Tropics. In: Photosynthesis: Photoreactions to Plant Productivity, Abrol et al. (Eds.). Kluwer Academic Publishers, Dodrecht, Netherlands, pp. 317-338.

13. Tefera, H., S. Ketema and T. Tessema, 1990. Variability, heritability and genetic advance in tef [Eragrostis tef Zucc. Trotter] cultivars. Trop. Agric. 67: 317-320. http://cat.inist.fr/?aModele $=$ afficheN\&cpsidt $=4959$ 972

14. Tefera, H. and S. Ketema, 2001. Production and importance of tef in Ethiopian agriculture. Narrowing the Rift: Tef research and development. Proceedings of the International Workshop on Tef Genetics and Improvement, Oct. 16-19, Ethiopian Agricultural Research Organization, Debre Zeit, Ethiopia, pp: 3-7.
15. Tefera, H. and G. Belay, 2006. Eragrostis tef (Zuccagni) Trotter. In: Plant Resources of Tropical Africa 1. Cereals and Pulses, Van der Vossen, H.A.M. and G.S. Mkamilo (Eds.). PROTA, Netherlands, ISBN: 9057821710, pp: 68-72.

16. Teklu, Y. and H. Tefera, 2005. Genetic improvement in grain yield potential and associated agronomic traits of tef (Eragrostis tef). Euphytica, $\quad 14: \quad 247-254$. http://cat.inist.fr/?aModele $=$ afficheN\&cpsidt $=1674$ 1625

17. Tulema, B., J.B. Aune, F.H. Johnson and B. Vanlauwe, 2008. The prospect of reduced tillage in tef (Eragrostis tef Zucca) in Gare area, West Shawa Zone of Oromiya, Ehthiopia. Soil Tillage Res., 99: 58-65. DOI: 10.1016/j.still.2007.12.001

18. Vavilov, N.I., 1951. The origin, variation, immunity and breeding of cultivated plants. Translated from Russian by K Stechert-Hafner, The Ronald Press, New York, pp: 37-38. 